\title{
INOVASI UNTUK MEDIA SOSIAL CIPTAAN INDONESIA
}

\author{
Richard Andrew ${ }^{1}$ \\ ${ }^{1}$ Jurusan Manajemen, Fakultas Ekonomi, Universitas Tarumanagara Jakarta \\ Email:richarda@untar.ac.id
}

\begin{abstract}
ABSTRAK
Di zaman modern dengan perubahan yang sangat cepat banyak produk yang diciptakan. Hal ini termasuk produk yang dihasilkan oleh anak bangsa. Akan tetapi, banyak orang Indonesia yang tidak menyadari kekhasan dari produk khas Indonesia. Hal ini kemudian diperparah dengan para produsen produk Indonesia tersebut yang acapkali menghasilkan produk dengan pola yang sama tanpa variasi dan keunikan yang membedakan secara signifikan dengan kompetitor lain. Lebih jauh lagi industri kreatif seperti media sosial kurang mendapatkan perhatian dari pemerintah dan masyarakat. Karena itu, maka penting sekali untuk industri media sosial untuk senantiasa mengembangkan produk guna meningkatkan nilai produk tersebut mulai dari peningkatan pelaksanaan proses kerja, pengembangan kemampuan teknis dan pengetahuan tenaga kerja serta menghasilkan keunggulan kompetitif dari alat - alat yang digunakan secara berkesinambungan. Penelitian ini bertujuan untuk memberikan saran agar media sosial Indonesia dapat bersaing dengan media sosial yang sudah ada dan berkembang terlebih dahulu di dunia. Adapun pendekatan yang digunakan pada penelitian ini adalah pendekatan kualitatif melalui studi literasi dengan hasil beberapa inovasi pada bagian pemasaran dan dari segi proses. Kedua hal ini merupakan hal kunci dari keberhasilan perusahaan yang menjadi objek penelitian. Secara singkat, dari penelitian ini dapat disimpulkan bahwa media sosial Indonesia masih dapat berkembang di masa yang akan datang.
\end{abstract}

Kata kunci: inovasi, pemasaran dan media sosial

\section{PENDAHULUAN}

Di era masa kini, ada banyak variasi dari produk yang diciptakan. Salah satu dari banyak produk yang diciptakan terjadi karena hadirnya adopsi teknologi termutakhir dalam suatu sebuah fenomena sosioteknis yang kompleks (McMaster \& Kautz: 2002). Hal ini mencakup penggunaan internet yang masif di segala bidang seperti bisnis, kesenian, komunikasi, teknik, psikologi, hukum dan bahkan kedokteran.

Akan tetapi salah satu variasi yang banyak mengubah hidup manusia di dunia adalah variasi di bidang media sosial. Media ini banyak digunakan mulai dari untuk fotografi, pesan singkat sampai, berdialog sampai dengan variasi lain yang lebih mendetail. Dengan variasi yang sebanyak itu dan masih akan terus bertambah, media sosial menjadi fenomena yang mentransformasi interaksi dan komunikasi di seluruh dunia (Edosomwan et al: 2011).

Perubahan ini termasuk pertumbuhan yang terjadi di Indonesia. Secara khusus, Chaffey (2018) mengungkapkan bahwa Indonesia adalah salah satu dari 10 negara pengguna media sosial terbesar di dunia. Walaupun demikian dalam penelitian tersebut juga diungkapkan bahwa Indonesia lebih banyak menggunakan media sosial luar negeri dibandingkan dengan media sosial yang dihasilkan oleh perusahaan Indonesia.

Oleh karena itu, pengguna lokal dari media sosial Indonesia hanyalah pada grup tertentu yang jumlahnya sangat kecil. Lebih jauh lagi, mereka tidak menyadari bahwa penggunaan media sosial karya anak bangsa dapat memberikan nilai tambah. Akan tetapi, media sosial Indonesia itu sendiri memang belum sempurna. Ini mencakup kekurangan budaya berinovasi pada sumber daya manusia yang berpendidikan dan kekurangan pengembangan fasilitas (Sutopo et al: 2015).

Selain itu, keselarasan antara bagian operasi di belakang dan bagian pemasaran di depan juga harus baik seperti yang diutarakan oleh Rhee dan Mehra (2006). Seperti yang kita ketahui banyak perusahaan di Indonesia terlalu berfokus di belakang sehingga produk menjadi kurang dikenal oleh 
masyarakat. Lebih parah lagi, beberapa perusahaan nakal hanya fokus di bagian depan sehingga kualitas dari produk setelah diuji sangat menyedihkan.

Padahal jika ditilik dari segi potensi, Indonesia merupakan negara yang termasuk penggila media sosial. Hal ini selaras dengan pernyataan Galih dan Ngazis (2012) yang mengungkapkan bahwa 90\% pengguna internet Indonesia menggunakan media sosial. Lebih hebat lagi, Damar (2016) mengungkapkan bahwa pertumbuhan aktivitas media sosial meningkat lebih dari $10 \%$ setiap tahunnya di Indonesia.

Banyak penelitian terdahulu yang dilakukan di Indonesia seputar media sosial karena media ini memberikan multi kegunaan di banyak sektor. Beberapa diantaranya adalah sebagai sarana pemasaran di sektor politik (Utomo: 2013), pengelolaan hubungan pelanggan (Supradono dan Hanum: 2011), konstruksi identitas (Maryani dan Arifin: 2012), promosi pariwisata (Umami: 2015) dan pengembangan hubungan interpersonal (Abadi et al: 2016).

Walaupun demikian, tentu setiap media sosial Indonesia perlu mempertimbangkan dampak dampak negatif dari media sosial yang menjadi masalah bangsa. Putri dan Nurwati (2016) menuturkan bahwa dampak itu mencakup terganggunya aktivitas pembelajaran, rentan terhadap kejahatan maupun penipuan serta berkurangnya kesopanan dan komunikasi dengan keluarga dalam kehidupan sehari - hari.

Berdasarkan dari masalah yang dikemukakan diatas tersebut maka dirumuskan tujuan utama penelitian ini yakni untuk melaksanakan inovasi pada media sosial ciptaan Indonesia. Peneliti berharap hal ini dapat membuat media sosial ciptaan Indonesia semakin banyak digunakan oleh masyarakat Indonesia dan tidak hanya itu tetapi juga digunakan secara rutin dengan bangga seperti yang dilakukan oleh negara - negara besar lain.

\section{METODE PENELITIAN}

Peneliti menggunakan metode penelitian kualitatif yang memungkinkan pemahaman lebih dalam terkait dengan praktek inovasi (Andrew et al: 2017). Lebih lanjut, Sugiyono (2005) menjabarkan bahwa penelitian kualitatif adalah penelitian yang digunakan untuk meneliti pada kondisi objek alamiah dengan peneliti sebagai instrumen kunci. Disinilah peneliti mengusulkan beberapa inovasi untuk diterapkan pada media sosial Indonesia seusai hasil studi literasi.

Salah satu dari model penelitian kualitatif yang banyak digunakan dan dapat diimplementasikan dengan cepat ke dunia bisnis secara umum dan media sosial Indonesia secara khusus adalah studi literasi yang dilakukan secara integratif. Integratif dalam hal ini berarti menggabung studi literasi dalam satu kesatuan. Studi ini juga mencakup identifikasi masalah, pencarian literatur yang tepat, evaluasi, analisis data dan terakhir mengambil kesimpulan (Andrew \& Suryawan: 2015).

Adapun populasi dari penelitian ini adalah semua media sosial yang digunakan di Indonesia secara luas dengan sampel yang diambil adalah beberapa media sosial dan kunci utama keberhasilannya. Sampling sendiri diambil dengan teknik purposive sampling yang menurut Supranto (2007) merupakan teknik pengambilan sampel yang tidak acak berdasarkan studi dari beberapa sumber.

\section{HASIL DAN PEMBAHASAN}

Dari hasil studi yang dilakukan peneliti, maka ditemukan beberapa hal yang dapat meningkatkan penggunaan media sosial Indonesia. Hal - hal tersebut diantaranya adalah kampanye pemasaran 
berkelanjutan, transparansi dalam komunikasi, mengurangi jumlah janji yang tidak sanggup ditepati, fokus terhadap kualitas, utamakan konten yang berasal dari masyarakat, perhatikan setiap penilaian dan ambil setiap peluang yang ada.

Kampanye pemasaran yang berkelanjutan sangat penting untuk dilakukan. Kampanye ini menurut Oden dan Larrson (2011) bisa berhasil jika dapat mengikat erat para pengguna dalam jangka waktu yang panjang, memberikan mereka sebuah kelebihan yang istimewa dan faktor sosial. Oleh sebab itu media yang digunakan untuk kampanye pemasaran haruslah melalui media yang sangat luas seperti WeChat di Tiongkok yang didukung penuh pemerintah.

Transparansi dalam komunikasi juga sangat penting. Virtanen (2014) mengungkapkan transparansi dalam komunikasi bisa dilakukan lewat keterbukaan, akuntabilitas dan kepercayaan. Oleh sebab itu penting untuk memiliki keterbukaan bagi pengguna secara gratis dan sistem keamanan jaringan yang sangat kuat seperti yang ditawarkan oleh Youtube yang merupakan bagian dari Google.

Lebih jauh lagi, jangan pernah menjanjikan sesuatu yang tidak pernah ditepati. Bailey (2005) mengungkapkan bahwa janji yang terlalu tinggi dengan hasil yang terlalu rendah merupakan kegagalan yang fatal. Sebagai contoh, ada Friendster yang gagal karena menjanjikan performa yang lebih cepat dan handal. Padahal dalam kenyataannya performa dari media sosial tersebut sangat kurang responsif sehingga tidak disukai para pengguna.

Lalu, fokus terhadap kualitas dikenal luas kepentingannya. Oleh sebab itu sosial media harus bisa memberikan kesesuaian terhadap ekspektasi, menyediakan branding, selalu berusaha aktual, berpartisipasi dalam dialog secara langsung termasuk interaksi antar individu dan antar grup, menjaga keamanan dan selalu beraksi untuk menjawab permintaan pasar. Hal inilah yang diberikan oleh Facebook sebagaimana dijelaskan oleh Owyang et al (2010).

Akan tetapi ada yang seringkali dilupakan yakni kebutuhan akan konten dari masyarakat. Ini sebabnya seluruh media sosial yang sukses harus memperhatikan 5 hal ini keaktifan, kemenarikan, kerendahan hati, ketidakformalan dan kejujuran (Kaplan \& Heinlein: 2010). Ini juga berlaku untuk semua pemilik dari media sosial tersebut beserta jajaran stakeholders yang terkait dengan media sosial tersebut seperti yang dilakukan oleh Twitter.

Berikutnya yang perlu diperhatikan adalah penilaian terhadap media sosial. Hal ini disebabkan karena media sosial juga memiliki peranan penting seperti sebagai bentuk modal bersosialisasi, pengikat hubungan dan bentuk partisipasi politik seperti yang diutarakan oleh Gil de Zuniga et al (2012). Penilaian yang baik terhadap Instagram jugalah yang membuat media sosial ini banyak digunakan oleh orang banyak.

Akhirnya, media sosial Indonesia juga perlu untuk mengambil peluang yang ada di dunia. Adapun pengambilan peluang tersebut seperti layanan multibahasa yang memudahkan pengguna dari negara yang banyak berkunjung ke Indonesia selain tentunya bahasa Inggris dan Indonesia. Selain itu juga dipertimbangkan untuk diperoleh dukungan penuh pemerintah dengan menekan penggunaan media sosial luar negeri saat media sosial Indonesia sudah terjamin kualitasnya.

Tentu saja kerjasama dengan perusahaan yang bergerak di bidang keuangan untuk kemudahan pembiayaan dan transaksi, bidang ritel untuk komunikasi pemasaran dan penyediaan barang secara resmi, bidang kartografi untuk penyediaan peta interaktif serta kemudahan navigasi, bidang 
informatika untuk penyediaan fitur - fitur baru yang berbeda ataupun serupa dengan peningkatan performa dibandingkan media sosial yang menjadi acuan patok duga.

\section{KESIMPULAN DAN SARAN}

Dari keseluruhan pembahasan tersebut, dapat disimpulkan bahwa media sosial Indonesia masih dapat berkembang jika memperhatikan dengan lebih luas tahapan saat membentuk kampanye pemasaran, melaksanakan transparansi komunikasi ke pelanggan internal maupun eksternal, pemenuhan kewajiban dengan seksama kepada seluruh stakeholders, pengendalian kualitas secara berkesinambungan, pengaktualisasian konten terutama yang positif, penerapan hasil penilaian yang obyektif dan pengambilan peluang terhadap kesempatan yang ada. Adapun penelitian ini di masa mendatang dapat dilanjutkan kajian lebih dalam dengan pengembangan yang didapat dari Forum Group Discussion (FGD) yang dilakukan antara beberapa pakar terkait di bidang ini.

\section{Ucapan Terima Kasih (Acknowledgement)}

Tim Penulis mengucapkan banyak terima kasih kepada semua pihak yang telah membantu proses penerbitan hasil penelitian ini khususnya kepada Ketua Program Studi S1 Manajemen Bapak Frangky Slamet, S.E., M.M., Ketua Jurusan Manajemen Dr. Keni, S.E., M.M., Dekan Fakultas Ekonomi Universitas Tarumanagara Dr. Sawidji Widoatmodjo, M.M., M.B.A. dan Rektor Universitas Tarumanagara Prof. Dr. Agustinus Purna Irawan, S.T., M.T.

\section{REFERENSI}

Abadi, T. W., Sukmawan, F., \& Utari, D. A. (2016). Media sosial dan pengembangan hubungan interpersonal remaja di Sidoarjo. KANAL: Jurnal Ilmu Komunikasi, 2(1), 95-106.

Andrew, R., Esmeralda, V. S., Willis, R., \& Sunjaya, A. (2017). Praktek Manajemen Inovasi di S1 Manajemen Bisnis Fakultas Ekonomi Universitas Tarumanagara. Jurnal Muara Ilmu Ekonomi dan Bisnis, 1(1).

Andrew, R. \& Suryawan, I. N. (2015). Studi Literasi Pengembangan Manajemen Klub Sepakbola di Indonesia. Modus Journals, 27(2), 175-182.

Bailey, T. M. (2005). Over Promise, Under Deliver: Pitfalls of a High Volume Practice. NASP Subrogator, Winter Issue.

Chaffey, D. (2018). Global Social Media Research Summary 2018. Smart Insights: Social Media Marketing.

Damar, Agustinus M. (2016). 3 Fakta Mengejutkan Pengguna Internet di Indonesia, February 14. http://tekno.liputan6.com/read/2435997/3-fakta-mengejutkan-pengguna-internet-diindonesia

Edosomwan, S., Prakasan, S. K., Kouame, D., Watson, J., \& Seymour, T. (2011). The History of Social Media and Its Impact on Business. Journal of Applied Management and entrepreneurship, 16(3), 79-91.

Galih, B., \& A. Ngazis. (2012). Entertainment Contents Get More Clicks. VivaNews.com, June 27. http://us.en.vivanews.com/news/read/330214-entertainment-contents-get-more-clicks. 
Gil de Zúñiga, H., Jung, N., \& Valenzuela, S. (2012). Social Media Use for News and Individuals' Social Capital, Civic Engagement and Political Participation. Journal of Computer Mediated Communication, 17(3), 319-336.

Kaplan, A. M., \& Haenlein, M. (2010). Users of the world, unite! The challenges and opportunities of Social Media. Business horizons, 53(1), 59-68.

Maryani, E., \& Arifin, H. S. (2012). Konstruksi Identitas Melalui Media Sosial. Journal of Communication Studies, 1(1).

McMaster, T. \& Kautz, K. (2002). A Short History of Diffusion, Proceedings of IFIP WG 8.6 5th International Working Conference on Diffusion, Adoption, and Implementation of Information Technology, eds D. Bunker, D. Wilson \& S. Elliot, IFIP, Sydney, pp. 10-22.

Odén, N., \& Larsson, R. S. (2011). What Makes a Marketing Campaign a Viral Success. A descriptive model exploring the mechanisms of viral marketing.

Owyang, J., Tran, C., \& Webber, A. (2010). The 8 Success Criteria for Facebook Page Marketing. Altimeter Group.

Putri, W. S. R., \& Nurwati, N. (2016). Pengaruh Media Sosial Terhadap Perilaku Remaja. Prosiding Penelitian dan Pengabdian kepada Masyarakat, 3(1).

Rhee, M. \& Mehra, S. (2006). Aligning Operations, Marketing and Competitive Strategies to Enhance Performance: An Empirical Test in the Retail Banking Industry. Omega, 34(5), 505-515.

Sugiyono, M. P. A., (2005). Metode Penelitian Kuantitatif, Kualitatif dan R\&D. Bandung: Alfabeta.

Supradono, B., \& Hanum, A. N. (2011). Peran Sosial Media untuk Manajemen Hubungan dengan Pelanggan pada Layanan E-Commerce. Value Added: Majalah Ekonomi dan Bisnis, 7(2), $33-45$.

Sutopo, W., Wicaksana, D. \& Nizam, M. (2015). Putting a Technology Innovation Culture to Realize Indonesian Vision 2025: A Case Study. Proceedings of the International Multiconference of Engineers and Computer Scientists 2015, Volume II.

Umami, Z. (2015). Social strategy pada media sosial untuk promosi pariwisata Daerah istimewa Yogyakarta. INTERAKSI: Jurnal Ilmu Komunikasi, 4(2), 195-201.

Utomo, W. P. (2013). Menimbang Media Sosial dalam Marketing Politik di Indonesia: Belajar dari Jokowi-Ahok di Pilkada DKI Jakarta 2012. Jurnal Ilmu Sosial dan Ilmu Politik, 17(1), 67-84.

Virtanen, J. (2014). Transparency in Development Communication. Finland: University of Jyvaskyla 
